\title{
Improving the quality and shelf-life of strawberries as coated with nano-edible films during storage
}

\author{
M. Shahat ${ }^{1}$, M. I. Mohamed ${ }^{1}$, A. S. Osheba ${ }^{2}$ and I. M. Taha ${ }^{1, *}$ \\ ${ }^{1}$ Food Science and Technology Department, Faculty of Agriculture, Al-Azhar University, Nasr City, Cairo, Egypt \\ ${ }^{2}$ Meat and Fish Technology Research Department, Food Technology Research Institute, Agricultural Research \\ Center, Giza, Egypt
}

*Correspondence: Ibrahimtaha164@azhar.edu.eg (I. Taha)

\begin{abstract}
Strawberry is a non-climacteric fruit but exhibits very limited postharvest life due to its rapid softening and decay. Therefore, the current study was carried out to evaluate the effect of edible coatings using chitosan $(\mathrm{CH})$ and chitosan nanoparticles (CHNPs) to improve the quality and extending the shelf life of strawberries during storage. Chitosan nanoparticles (CHNPs) were prepared by an ionic gelation method. The size and shape of the synthesized CHNPs were observed by transmission electron microscopy (TEM) technique. The strawberry samples were stored (after coating) at ambient temperature $\left(25 \pm 3^{\circ} \mathrm{C}\right)$ and cold temperature $\left(6 \pm 2^{\circ} \mathrm{C}\right)$ then, we evaluated the effectiveness of edible coating for physicochemical and microbiological properties, as well as the shelf-life during storage. The results of the TEM showed that the average particle size was 18.8-21.8 nm. At the different temperatures of storage, the samples coated with CHNPs had lower values of weight loss, decay, total soluble solids, and malondialdehyde concentrations. The same treatment had higher levels of total acidity and anthocyanin compared to the $\mathrm{CH}$ and uncoated treatments, that lead to preserving their quality properties and extending the shelf-life. Also, counts of total aerobic, mold, and yeast for strawberry samples treated by CHNPs were lower than those for $\mathrm{CH}$ and control treatment during the storage. In conclusion, the antimicrobial edible coating by CHNPs improved the qualitative characteristics and increased the shelf-life from 2 to 6 days for fruits stored at $25 \pm 3^{\circ} \mathrm{C}$ and from 8 to 16 days for samples stored at $6 \pm 2^{\circ} \mathrm{C}$.
\end{abstract}

Keywords: Strawberry, edible coatings, chitosan nanoparticles, TEM, shelf-life.

\section{INTRODUCTION}

Supermarkets face challenges to keep the freshness of fruits and vegetables for longer times. During postharvest transportation and storage, fresh fruits undergo quality deteriorations due to the various physiology reactions and processes. These physiological changes are directly influenced by the surrounding environment, which leads to loss of water, texture, color and nutrients (Gong et al., 2018). One major contributor to these losses is represented by the food spoilage, which was induced by a wide range of microorganisms (Tesfaye, 2019). In developing countries, the percentages of product losses are quite high due to a lack of appropriate technologies for postharvest storage of fruits and vegetables (Kumar et al., 2019).

Strawberry fruits are one of the most consumed berries in worldwide (Rahimi et al., 2018). Principally, it is consumed as fresh products for its sensory features, such as color, texture, aroma and flavor. In addition, it is a vegetable crop rich in vitamins (A, B and $C$ ) and minerals $(\mathrm{K}, \mathrm{Ca}, \mathrm{Mg}, \mathrm{Fe}$ and $\mathrm{S})$ that possess functional properties (Abozaid and Eldeeb, 2019).
Egypt is the fourth-largest producer of strawberry worldwide after the United States, Turkey, and Spain with production 479 thousand tons in 2018. Also, strawberry is one of the most important crops of exported vegetables. Egyptian Export statistics indicate that Egyptian strawberry exports to be about 139 thousand tons in 2018 (CAPMS, 2019). Fresh strawberries are highly perishable, a nonclimacteric fruit. However, postharvest handling and storage of fresh strawberries are difficult mostly due to their high susceptibility to mechanical injury, water loss, microbial decay, physiological deterioration and high respiration rate (Liu et al., 2018a).

The food industry is making great efforts to minimize the losses and extend the shelf life. Therefore, there is a constant search for new technologies that can help in achieving these goals. Nanotechnology is one of the major innovations which have already been applied in this area (Zorraquín-Peña et al., 2020). In the last several years, the edible coatings have been widely studied for preserving fruits and vegetables. Previous studies related to chitosan indicated its potential to prolong storage period and control decay of many fruits. Chitosan (b$(1,4)$-2-amino-2-deoxy-d-glucose) is a natural polymer known by its biological properties, such as non-toxicity, biocompatibility and 
biodegradability with excellent film forming properties (Younes and Rinaudo 2015). Chitosan nanoparticles (CHNPs) have characteristic features of chitosan biopolymer and nanoparticles such as quantum size effects, and they possess wide applications in the antimicrobial agents (Kalaivani et al., 2020). The unique physical and chemical characteristics of CHNPs are consequences of reduction in particle size and increasing the surface to particle size ratio in nanoparticles (Roy et al., 2019).

Many studies have focused on the efficacy of chitosan and nano-chitosan, and its application as a natural preservative in foods. In the study by Melo et al. (2018) CHNPs were responsible for delaying the ripening process of the grapes resulting in decreased weight loss, soluble solids and reducing sugar content and increased moisture retention and preservation of the titratable acidity values. Moreover, CHNPs exhibited an inhibitory effect against pathogenic foodborne bacteria.

Also, Esyanti et al. (2019) studied the effect of CHNPs as a good coat on the Cavendish bananas ripening process. The observations of physical characteristics of bananas ripening showed that fruits coated with CHNPs $0.2 \%$ have a slower skin discoloration by 2-3 days compared to control treatment.

Recently, Hasheminejad and Khodaiyan (2020) investigated the effect of coating on shelflife and quality of minimally processed pomegranate arils during storage at $5{ }^{\circ} \mathrm{C}$. The CHNPs were the most effective coating for extending shelf-life and controlling undesirable microbial, physicochemical and sensory alterations of pomegranate arils.

This study aims to evaluate formulations of chitosan and chitosan nanoparticle as antimicrobial to extend the strawberry storage at different temperatures. Also, we aimed to study the characteristics of physicochemical, microbiological and overall acceptability for coated fruits with each formulation and to compare them with uncoated sample (control) during the storage periods.

\section{MATERIALS AND METHODS}

\section{Chemicals}

Chitosan powder (assay 99\%, degree of deacetylation $80 \%$ ) was purchased from Suvchem, Mumbai, India. Acetic acid, sodium tripolyphosphate (TPP) and sodium hydroxide, glycerin, trichloroacetic acid and thiobarbituric acid were purchased from El-Nasr
Pharmaceutical Chemicals Company, Cairo, Egypt.

\section{Strawberry fruits}

Fresh strawberry fruits (Fragaria ananassa) "Camarosa" were obtained from AL-Mollak Farm, Abo-Hamad City, Al-Sharqia Governorate, Egypt. The fruits were harvested on mid-April, 2019 when bright red color (3/4 of surface showing red) at the same ripening stage. The fruits were selected based on the uniform color, same size and no pests, as well as the absence of blemishes or disease, with no physical damage.

\section{Methods}

\section{Preparation of chitosan nanoparticles}

Chitosan nanoparticles (CHNPs) were prepared by ionic gelation method as described by Vimal et al. (2013). Chitosan solution was prepared by dissolving $1.0 \mathrm{~g}$ chitosan in $100 \mathrm{~mL}$ acetic acid (1\%) and leaving it under stirring for until the solution was transparent. The $\mathrm{pH}$ was adjusted to $\mathrm{pH} 5.5$ with $0.01 \mathrm{~N} \mathrm{NaOH}$. Then, sodium tripolyphosphate solution $(1 \%)$ was added to chitosan solution dropwise under magnetic stirring. Once the dropwise addition was completed, the resulting suspension was then left under stirring for $45 \mathrm{~min}$.

\section{Preparation of coated strawberry samples}

The coating solutions were prepared by adding $\mathrm{CH}$ or CHNPs (at concentrations 0.5 and $1 \%$ ) and glycerol as a plasticizer (1.5:100 $\mathrm{v} / \mathrm{v})$. The solution was stirred over a magnetic stirrer for $15 \mathrm{~min}$ at ambient temperature before use. The strawberries were washed with portable water and was left for airdrying. The strawberries were randomly distributed into five samples. Four samples were treated (coating with CHNPs or with $\mathrm{CH}$ at different concentrations) and the fifth sample was used as control (untreated). After that samples were dipped in the different coating solutions for 3 min and left to let it dried, packaged in polypropylene container, then were divided into two groups: the first was kept at ambient temperature $\left(25 \pm 3^{\circ} \mathrm{C}\right)$ and the other sample kept at cold temperature $\left(6 \pm 2^{\circ} \mathrm{C}\right)$. The samples were periodically analyzed every 2 days during the storage at $25 \pm 3^{\circ} \mathrm{C}$, and every 4 days during the storage at $6 \pm 2^{\circ} \mathrm{C}$ until the samples spoilage.

\section{Analytical Methods}

\section{Characterization of synthesized chitosan nanoparticles}

The morphological features of CHNPs were examined by High-Resolution Transmission 
Electron Microscopy (TEM) which provides accurate information about the size and shape of the formed nanoparticles. TEM characterization is performed using (JEOL, JEM-1230, Japan) instrument with an acceleration voltage of $120 \mathrm{kV}$.

Determination of physiochemical quality criteria for coated fruits.

\section{Weight loss (\%)}

The weight loss was calculated as the percentage loss of initial weight as reported by Qin et al. (2015).

\section{Total soluble solids (\%)}

Total soluble solids (TSS) were determined by the refractometric method according to AOAC (2016) using a hand refractometer and the results were expressed as \% TSS.

\section{Total titratable acidity (\%)}

Total titratable acidity (TA \%) was determined according to method of Hajji et al. (2018) based on content of citric acid per $100 \mathrm{~g}$ of fresh weight.

\section{Malondialdehyde concentration}

The malondialdehyde concentration (MDA) was measured according to method of Liu et al. (2018).

\section{Measurement of anthocyanin content}

Anthocyanin content was extracted by the method of Holzwarth et al. (2012). Then it is calculated according to Vargas et al. (2006).

Determination of microbiological quality
criteria

\section{Inspection of decay}

At each time of analysis, visually decayed fruits were removed and the decay percentage was calculated as the number of decayed fruits according to the method of Li et al. (2019).

\section{Total bacterial count}

The total aerobic bacteria count was determined according to the procedures described by FAO/WHO (1995).

\section{Yeast and mold counts}

The yeast and mold counts were determined by the method described by APHA (1992).

\section{Measurement of shelf-life}

The shelf-life of strawberry samples was calculated by counting the days required for them when they remained still acceptable for marketing according to Mondal (2000).

\section{Statistical analysis}

The experiment was conducted in a completely randomized design with three replications. The statistical analysis was performed using the Cohort software CoStat (version 6.45). One-way ANOVA at the level of significance of $p<0.05$, using the Duncan test was performed to compare the means among different treatments.

\section{RESULTS AND DISCUSSION}

Particle size and morphological analysis of chitosan nanoparticles

Transmission electron microscope (TEM) imaging showed the morphological properties and surface appearance of CHNPs, which had a nearly spherical shape, smooth surface with average particle size $18.8-21.8 \mathrm{~nm}$ as illustrated in Fig (1).

Effect of coating with nanoparticles on quality criteria of strawberry fruits during storage

\section{Weight losses (\%)}

Strawberry fruits are highly susceptible to rapid loss of water, resulting in very thin skin, which induced the shrinkage and weakening of tissues (Otoni et al., 2017). The effect of coatings on weight losses for strawberry fruits treated by $\mathrm{CH}$ or $\mathrm{CHNPs}$ at different concentrations during storage was studied and results are presented in Table (1).

During a prolonged storage periods, a gradually increase $(p<0.05)$ in weight loss $(\%)$ was observed for all samples at different temperatures, which might be related to the continuous movement of water from the fruits to the surrounding environment (Duan et al., 2011). These results are in similar with the findings of Nguyen et al. (2020) who reported that the weight loss (\%) was gradually increased with increasing of storage periods. At different storage temperatures, coating significantly reduced $(p<0.05)$ weight loss percentage compared to uncoated strawberry throughout storage. Also, based on the mean comparison, it can be concluded that, the weight loss $\%$ at $25 \pm 3^{\circ} \mathrm{C}$ in all treatments was more than those at $6 \pm 2^{\circ} \mathrm{C}$.

During the storage at $25 \pm 3^{\circ} \mathrm{C}$ after the six days of storage, the highest weight losses $(p<$ $0.05)$ were noted for the untreated fruits $(28 \%)$ followed by the sample treated with $\mathrm{CH} 0.5 \%$ (23\%). While, the lowest losses were observed in the sample treated with CHNPs 1\% (13.5\%).

With regard to the effect of cold storage $\left(6 \pm 2^{\circ} \mathrm{C}\right)$, at the end of storage (16 days), surely 
coating formulas significantly reduced $(p<0.05)$ weight loss in all coated samples compared to uncoated sample. The uncoated strawberry recorded weight loss of $13.65 \%$. While, the rates of weight loss in treated samples ranged from 3.85 to $9.75 \%$ at the same storage period. It is worth noting that the lowest loss $(\mathrm{p}<0.05)$ was observed in the sample treated by CHNPs $1 \%$ (3.85\%).

Generally, the results are consistent with previous studies showing a reduction in weight loss was related to the effects of coatings. These effects served as semipermeable barriers against oxygen, carbon dioxide, and moisture, thus reducing respiration, water loss and oxidation reactions. Also, nanoparticles are responsible for creating a zigzag in the film structure, which would hinder the passage of permeates such as $\mathrm{O}_{2}, \mathrm{Co}_{2}$ and water vapor as reported by Svagan et al. (2009).

\section{Total soluble solids (TSS)}

Total soluble solids (TSS) play an important role in affecting fruit quality and consumer acceptability. TSS content of strawberry samples as affected by coatings with $\mathrm{CH}$ or it is nanoparticles during storage at room and cold temperatures for different periods are presented in Table (2). Data proved that strawberry fruits stored on room temperature recorded higher values in Brix percentage than those stored on fridge conditions. TSS content of samples ranged from 5.6 to $5.8 \%$. Also, it could be observed that TSS content of all samples was increased during storage periods. These results are in agreement with Zhang et al. (2018) who indicated that TSS of fruits increased during storage due to breakdown of starch into soluble sugars or the hydrolysis of cell walls.

During the storage at room temperature, there was no considerable difference in changes in TSS content of coated samples. In contrast, there was a considerable difference $(p<0.05)$ in changes in TSS content between these samples and uncoated fruit sample (control). Also, it could be observed that TSS content of all samples was increased during storage periods. At the $2^{\text {nd }}$ day of storage, the control sample showed the highest content of TSS $(6.58 \%)$ compared to the coated samples which ranged from 5.83 to $6.00 \%$. At the $4^{\text {th }}$ day of storage, TSS contents reached to $6.12,6.05,6.22$ and $6.18 \%$ for strawberry sample treated by $\mathrm{CH}$ (at 0.5 and $1 \%$ ) and CHNPs (at 0.5 and 1\%), respectively. While, at the end of storage all tested samples were spoiled, except sample treated by CHNPs at $1 \%$. On the other side, at cold storage, TSS content for all samples showed a slight decrease at the end of storage period. On the $8^{\text {th }}$ days, TSS content of uncoated strawberry and treated with $\mathrm{CH} 0.5 \%$ was decreased to 5.65 and $5.75 \%$, respectively, while, other coated samples had a continuous increase and recorded 5.81, 6.03 and 5.79 for $\mathrm{CH} 1 \%$ and CHNPs (at 0.5 and $1 \%$ ), respectively. Similarly, at the $12^{\text {th }}$ days, TSS content of samples treated with $\mathrm{CH}$ (at 0.5 and $1 \%$ ) was decreased to 5.66 and $5.74 \%$, while, the other coated samples had a continuous increase and recorded 6.19 and 5.97 for CHNPs (at 0.5 and $1 \%)$.

At the end of storage (the $16^{\text {th }}$ day), TSS content was decreased in the all treated samples and recorded 5.56, 6.1 and 5.95 for $\mathrm{CH} \mathrm{1 \%} \mathrm{and}$ CHNPs (at 0.5 and 1\%), respectively. These results are in line with those reported by Nguyen et al. (2020), who found that TSS of strawberry fruits were increased and then were slowly declined due to hydrolysis until the end of the storage time.

\section{Titratable acidity content}

The organic non-volatile acids are among the most important components and represent the second most important component of strawberry flavor, after soluble sugars (Khalifa et al., 2016). The effect of coatings by $\mathrm{CH}$ and CHNPs on titratable acidity content for strawberry fruits is presented in Table (3). The result indicates that no significant differences were recorded in titratable acidity content between uncoated and all coated samples. The titratable acidity contents were found to be 0.48 to $0.53 \mathrm{~g}$ citric acid $/ 100 \mathrm{~g}$ for samples at initial storage.

During the storage at room temperature, TA contents didn't show significant changes from effect of storage periods in strawberry samples treated by CHNPs. On the contrary, significant changes $(p<0.05)$ in TA contents were observed between uncoated (control) and strawberries treated by $\mathrm{CH}$. This observation of TA variation was similar to those observations of Thakur et al. (2018). TA content in strawberries reduced from $0.48,0.52,0.51,0.53$ and $0.52 \%$ at initial storage to $0.37,0.45,0.47,0.48$ and $0.49 \%$ after the $2^{\text {nd }}$ day of storage for control and samples coated with $\mathrm{CH}$ (at 0.5 and 1\%) and CHNPs (at 0.5 and $1 \%$ ), respectively. These values reached to $0.34,0.36,0.43$ and $0.43 \%$ for the same samples (without control) at the $4^{\text {th }}$ day. At the end of storage (6 days), all samples were spoiled, except the sample treated with CHNPs $1 \%$ recorded TA content $(40 \%)$.

With regard to the storage of strawberry samples on a cold temperature, no considerable 
changes were observed in TA contents between the samples during different storage periods. On the $8^{\text {th }}$ day, the highest reduction in TA content was recorded in uncoated sample $(10 \%)$. While, the lowest reduction was observed in the sample treated by CHNPs $1 \%$ (4\%) compared to the other samples that ranged from 5 to $6 \%$ as portrayed in Table (3). On the $12^{\text {th }}$ day of storage, TA contents were reduced to $0.44,0.44,0.45$ and $0.45 \%$ for $\mathrm{CH}$ (at 0.5 and $1 \%$ ) and CHNPs (at 0.5 and $1 \%$ ), respectively. At the end of cold storage (16 days), the minimum reduction in TA for strawberry samples was noted in sample treated with CHNPs 1\% (8\%). Nano-membrane could inhibit the respiration of samples and slow down the consumption of acid in the physiological metabolic activities of fruits. Therefore, the nano-membrane can effectively slow down the downward trend of titratable acid and extending the shelf life of the fruits (Zhang et al., 2018).

\section{Anthocyanin content}

Colour is the most important factor which describes the fruit general quality. The effect of coating on anthocyanin content for strawberry fruits treated by $\mathrm{CH}$ or CHNPs at different levels was studied and the results are presented in Table (4). The the results indicated that no significant differences were recorded in anthocyanin content between uncoated sample and all coated samples at initial storage, but it significantly differed $(p<0.05)$ during different storage periods. In general, it is noticed that the anthocyanin content in strawberry fruits was increased with the progress in storage periods and then was decreased at the end of storage periods. These results were in line with the previous study of Nguyen et al. (2020).

During storage at room temperature, the uncoated sample showed a higher significantly increase $(52.76 \mathrm{mg} / 100 \mathrm{~g})$ than the coated samples $(p<0.05)$, which ranged from 46.58 to $48.88 \mathrm{mg} / 100 \mathrm{~g}$ at the $2^{\text {nd }}$ day of storage. It could be explained as a natural process during fruit ripening, besides the effect of high weight loss that could contribute to the concentration of pigments, according to Badawy et al. (2017). Also, these results are in agreement with those obtained by Rahimi et al. (2018), who found that uncoated strawberry had a greater anthocyanin content than coated fruits. On the $4^{\text {th }}$ day, the anthocyanin contents recorded 44.60, 47.80, 50.96 and $54.70 \mathrm{mg} / 100 \mathrm{~g}$ for $\mathrm{CH}$ (at 0.5 and $1 \%$ ) and CHNPs (at 0.5 and 1\%), respectively. At the end of storage (the $6^{\text {th }}$ day), all samples were spoiled, except the sample treated with CHNPs $1 \%$ which recorded $58.25 \mathrm{mg} / 100 \mathrm{~g}$.
On the other hand, during the storage on cold temperature, a slow increase was recorded in the anthocyanin content to $44.68,39.62,37.00$, 36.92 and $34.57 \mathrm{mg} / 100 \mathrm{~g}$ at the $4^{\text {th }}$ day for control and samples coated with $\mathrm{CH}$ (at 0.5 and $1 \%$ ) and CHNPs (at 0.5 and 1\%), respectively. At the $8^{\text {th }}$ day of storage, a decrease in anthocyanin content was occurred for uncoated sample $(38.36 \mathrm{mg} / 100 \mathrm{~g})$, while the other treated samples had a continuous increase and the values ranged from 38 to $43.8 \mathrm{mg} / 100 \mathrm{~g}$. At the end of storage (the $16^{\text {th }}$ day), anthocyanin contents were observed in all remaining samples and reached to $40.17,47.25$ and 45.56 , $\mathrm{mg} / 100 \mathrm{~g}$ for samples treated with $\mathrm{CH} 1 \%$ and CHNPs (at 0.5 and 1\%), respectively. These results in agreement with the results obtained by Qamar et al. (2018), who showed less change in anthocyanin content in fruits of raspberry and table grapes coated with chitosan.

\section{Malondialdehyde concentration}

The malondialdehyde (MDA) is a secondary end final product of membrane lipid oxidation. It is usually considered as an indicator to assess the progress of fruit ripening which represents the structural integrity of the membranes of plants (Gao et al., 2016).

The effect of coatings with $\mathrm{CH}$ or CHNPs during storage on MDA concentration for strawberry fruits is presented in Tables (5). The finding indicated that no differences were observed in MDA concentrations between uncoated and all coated samples at the initial storage of MDA concentration in the all tested strawberry samples was found to be 2.45 $\mathrm{mmol} / \mathrm{g})$, but it differed significantly $(p<0.05)$ during the different storage periods. In general, during prolonged storage periods, a gradual increase $(p<0.05)$ was detected in MDA concentrations for all coated and uncoated samples. These results are in agreement with a previous study which reported that MDA concentration was gradually increased with prolonged storage periods for strawberry fruits (Nguyen et al., 2020). Also, the uncoated sample recorded a higher MDA concentration $(p<$ 0.05)than those for coated samples at different storage temperatures. To compare the effect of storage temperatures on the MDA concentration, this study indicated that the storage at room conditions led to higher MDA concentration than those for the samples stored at fridge conditions.

During the storage at room temperature on the $2^{\text {nd }}$ day, the uncoated sample showed the highest value of MDA (3.95 mmol/g) compared to the coated samples which reached to $3.5,3.38$, 
3.39 and 3.28 for $\mathrm{CH}$ (at 0.5 and $1 \%$ ) and CHNPs (at 0.5 and $1 \%$ ), respectively. at the $4^{\text {th }}$ day, the uncoated sample was spoiled and MDA concentration in coated samples reached to $4.65,4.38,4.35$ and $4.21 \mathrm{mmol} / \mathrm{g}$. At the end of the storage period (the $6^{\text {th }}$ day), all the samples were spoiled, except the sample coated by CHNPs at $1 \%$ which had $5.04 \mathrm{mmol} / \mathrm{g}$ of MDA concentration.

At cold a temperature, due to the decrease in respiration trend, the chemical changes in fruit tissue occur slowly. So, the changes of MDA were slower than those changes at the room temperature. The MDA values of all strawberry samples were clearly increased $(p<0.05)$ during the storage period and the MDA value of uncoated sample was increased to $4.29 \mathrm{mmol} / \mathrm{g}$ after 8 days then it was spoiled on the $12^{\text {th }}$ day. While, the rate of MDA increasing was lower in the coated samples. At the end storage (the $16^{\text {th }}$ day), the MDA values reached to 5.53, 5.62 and $5.18 \mathrm{mmol} / \mathrm{g}$ for coated samples by $\mathrm{CH} 1 \%$ and CHNPs (at 0.5 and $1 \%$ ), respectively.

According to the previous results, CHNPs coatings could be effective in maintaining lower MDA concentration during the storage at room or fridge temperatures. These results suggest that, the nano-coatings are a promising tool for preventing postharvest oxidative damage during storage.

\section{Visual decay percentage}

Decay is one of the key factors which responsible for the postharvest losses in fruits and vegetables. Fruits are directly exposed to the contaminating microorganisms through soil, dust, water and postharvest processing equipment (Xi et al., 2017). The effect of coatings on decay percentage for strawberry fruits treated by $\mathrm{CH}$ or CHNPs is presented in Table (6). There is a marked increase in the number of infected strawberries during prolonged storage periods for all the coated and uncoated samples. However, the coating treatments reduced the decay percentage in all strawberry fruits during the storage periods. These results are in line with those reported by Bose et al. (2019) who showed that chitosan coatings are effective in reducing fungal decay at postharvest stages of strawberry fruits.

During the storage at room temperature, visual decay started quickly on the control fruits with $10 \%$ of fruits exhibited the sign of infection after 2 days of storage. The infection rates were increased with increasing storage periods and the infection percentage recorded 80 and $100 \%$ on the $4^{\text {th }}$ day and at the end storage period (after 6 days). On the other hand, the coated strawberry fruits started to exhibit the first infection signs of decay at the $4^{\text {th }}$ day of storage and the samples showed 40, 30, 20 and $10 \%$ infection for treated by $\mathrm{CH}$ (at 0.5 and $1 \%$ ) and CHNPs (at 0.5 and 1\%), respectively. At the end storage period (the $6^{\text {th }}$ day), the infection rate reached to $100,75,70$ and $50 \%$ for the same fruits.

Regarding the effect of cold storage on strawberry fruits, the uncoated strawberry fruits showed signs of decay at the $4^{\text {th }}$ day $(15 \%)$. On the $8^{\text {th }}$ day, $45 \%$ of uncoated fruits were infected. In contrast, no sign of visible infestation in the coated strawberry fruits was detected up to the $8^{\text {th }}$ day of storage, except the strawberry sample coated with $0.5 \% \mathrm{CH}$ which recorded $10 \%$ of the infection rate. On the $12^{\text {th }}$ day of cold storage, the infection rates were increased in uncoated strawberry and recorded $100 \%$. On the other side, the other coated strawberry samples started to exhibit first signs infection of decay and showed 60, 20, 25 and 10 $\%$ infection for the samples treated with $\mathrm{CH}$ (at 0.5 and $1 \%$ ) and CHNPs (at 0.5 and $1 \%$ ), respectively. At the end storage, (the $16^{\text {th }}$ day) $100 \%$ of fruits treated with $\mathrm{CH} 0.5 \%$ were infected. While, the infection of the other coated strawberry fruits was 70, 60 and $40 \%$ for samples treated with $\mathrm{CH} 1 \%$ and CHNPs (at 0.5 and $1 \%$ ), respectively.

\section{Microbial load}

The control of the microbial load has a great important role in maintaining high-quality attributes, especially the hygienic quality of the final product (Rani et al., 2017). The changes of TBC, mold and yeast counts during storage for uncoated and coated strawberry fruits are exhibited in Table (7). The microbial load of all strawberry samples was influenced by coating treatments during storage. The TBC and mold and yeast were linearly increased with progressing the storage periods of all samples, especially the control sample which was rapidly increased than the other coated samples. Moreover, all coating treatments had slower rates for the growth of TBC, mold and yeast counts during the storage periods.

After the $2^{\text {nd }}$ day of storage at room temperature, the initial values of TBC, mold and yeast were raised to 4.37 and $4.02 \log$ CFU/g for uncoated strawberry compared to $3.95,3.62,3.69$ and $3.45 \log$ CFU/g of TBC in the samples coated with $\mathrm{CH}$ (at 0.5 and $1 \%$ ) and CHNPs (at 0.5 and 1\%), respectively; and to $3.90,3.83,3.85$ and $3.42 \log$ CFU/g of mold and yeast for the same samples. At the $4^{\text {th }}$ day of storage, TBC values of coated strawberry 
samples were ranged from 4.62 to $5.63 \mathrm{log}$ $\mathrm{CFU} / \mathrm{g}$, compared to uncoated sample, which was $5.97 \log \mathrm{CFU} / \mathrm{g}$. Also, all coated samples were lower in mold and yeast counts than the uncoated samples. Where, mold and yeast counts ranged from 4.58 to $5.60 \mathrm{log} \mathrm{CFU} / \mathrm{g}$ against $5.85 \mathrm{CFU} / \mathrm{g}$ for uncoated strawberry sample.

At the $6^{\text {th }}$ day of storage, the uncoated strawberry sample and coated sample with $\mathrm{CH}$ $0.5 \%$ were spoiled. The other samples recoded TBC 6.15, 6.1 and $5.68 \mathrm{log}$ CFU/g for samples coated with $\mathrm{CH} 1 \%$ and CHNPs (at 0.5 and $1 \%$ ), respectively. While, mold and yeast counts for the same samples were 5.92, 5.83 and $5.51 \mathrm{log}$ $\mathrm{CFU} / \mathrm{g}$. These results are in line with the results obtained by Khan et al. (2019) who showed that the strawberries coated with chitosan as edible coatings supplemented with carotenoproteins possess a lower number of molds and yeast growth compared to the uncoated fruits.

With regard to the effect of storage on cold temperature, Table (7) indicates that TBC, mold and yeast counts were rapidly increased in uncoated strawberry than those in coated samples, starting from the fourth day. At the $8^{\text {th }}$ day of cold storage, the initial values of TBC, mold and yeast counts were raised to 6.65 and $5.82 \log \mathrm{CFU} / \mathrm{g}$ for uncoated strawberry compared to $4.58,4.01,3.88$ and $3.56 \log$ CFU/g for samples coated with $\mathrm{CH}$ (at 0.5 and $1 \%$ ) and CHNPs (at 0.5 and 1\%), respectively. While, mold and yeast counts reached to 5.1, 4.78, 4.73 and $4.45 \log \mathrm{CFU} / \mathrm{g}$ for the same samples.

Finally, the results indicated that, the strawberry fruits coated with $\mathrm{CH}$ had a lower microbial load than uncoated, while it had a higher microbial load than nano-coated samples throughout the storage. This may be because the CHNPs can effectively inhibit the growth of fruit microorganisms. These results are consistent with findings of Fan et al. (2017) who found that nano active film is better for food preservation.

\section{Shelf-life of strawberry fruits}

The most important advantage of any antimicrobial technology is the ability to extend the shelf-life of food system. Shelf-life is based on the physical appearance as judged by the retention of color, glossy appearance and pathogenic decay (Moradinezhad and Jahani 2019). In general, the shelf-life qualities of strawberry fruits stored at refrigerator conditions $\left(6 \pm 2^{\circ} \mathrm{C}\right)$ were better than those stored at room conditions $\left(25 \pm 3^{\circ} \mathrm{C}\right)$. Data presented in Fig (2) reveals that different strawberries treatments can modify their spoilage profile and extend the shelf-life. For instance, the uncoated fruits were spoiled at the $4^{\text {th }}$ day of storage on room temperature and after the $8^{\text {th }}$ days for storage at cold conditions. Thus, the samples coated with $\mathrm{CH} 0.5 \%$ had a shelf-life of 4 days for the storage at room temperature, while the same sample stored at fridge conditions had a shelf-life of 12 day. Whereas, the samples coated with $\mathrm{CH} 1 \%$ and CHNPs $0.5 \%$ had a shelf-life of 4 and 16 days at room and cold temperatures, respectively. On the other hand, the sample coated with CHNPs $1 \%$ had a shelf-life of 6 and 16 days at the room and cold temperatures, respectively. This indicates a significant economic and very promising effects for strawberry fruits producers.

\section{CONCLUSION}

Coatings represent one of the most important methods which used for preserving the quality of the fruits and vegetables. The application of CHNPs appears to be highly promising in the field of food processing for extending the shelf-life of strawberries during storage. Based on comprehensive comparison and evaluation, strawberries coated by CHNPs could be kept in good quality for 16 days at $6 \pm 2^{\circ} \mathrm{C}$ and for 6 days at $25 \pm 3^{\circ} \mathrm{C}$.

\section{REFERENCES}

A.O.A.C., 2016. Official Methods of Analysis of the Association of Official Analytical Chemists International (20th Edition). Maryland, USA.

A.P.H.A., 1992. American Public Health Association. Compendium of methods for the microbiological examination of foods, pp 75-97. APHA, Washington, D.C., U.S A.

Abozaid, D.E., Eldeeb, S.M., 2019. Using multi objectives transportation model in distribution strawberry crop in Egypt. Middle East J., 8 (4), 1319-1324.

Badawy, M.E., Rabea, E.I., El-Nouby, M., Ismail, R.I., Taktak, N.E., 2017. Strawberry shelf life, composition, and enzymes activity in response to edible chitosan coatings. International Int. Journal of. Fruit ScienceSci., 17 (2), 117-136.

Bose, S.K., Howlader, P., Jia, X., Wang, W., Yin, H., 2019. Alginate oligosaccharide postharvest treatment preserves fruit quality and increase storage life via Abscisic acid signaling in strawberry. Food ChemistryChem., 283, 665674.

C.A.P.M.S., 2019. Central Agency for Public Mobilization and Statistics. Egypt statistics. Final results of 2017 Census. https://www.capmas.gov.eg.

Costat., 1986. Costat - Statistics Software Powerful. Easy to use. Reasonably priced. Available from: http://cohort.com/costat.html. CoHort Software, 798 Lighthouse Ave. PMB 320 Monterey, CA 93940, U.S.A. 
Duan, J., Wu, R., Strik, B.C., Zhao, Y., 2011. Effect of edible coatings on the quality of fresh blueberries (Duke and Elliott) under commercial storage conditions. Postharvest Biol. Technol., 59 (1), 71-79.

Esyanti, R.R., Zaskia, H., Amalia, A., 2019. Chitosan nanoparticle-based coating as post-harvest technology in banana. J. Phys. 1204 (1), 012109.

Fan, J., Chu, Z., Li, L., Zhao, T., Yin, M., Qin, Y., 2017. Physicochemical properties and microbial quality of Tremella aurantialba packed in antimicrobial composite films. Molecules, 22 (3), 500.

$\mathrm{FAO} / \mathrm{WHO}$, 1995. Ice in fisheries food and agricultural organization of the United Nations, Fum /Rs, Rev.1, Rome.

Gao, H., Zhang, Z.K., Chai, H.K., Cheng, N., Yang, Y., Wang, D.N., Cao, W., 2016. Melatonin treatment delays postharvest senescence and regulates reactive oxygen species metabolism in peach fruit. Postharvest Biol. Technol., 118, 103-110.

Gong, T., Li, C., Bian, B., Wu, Y., Dawuda, M.M., Liao, W., 2018. Advances in application of small molecule compounds for extending the shelf life of perishable horticultural products: a review. Sci. Hort., 230, 25-34.

Hajji, S., Younes, I., Affes, S., Boufi, S., Nasri, M. 2018. Optimization of the formulation of chitosan edible coatings supplemented with carotenoproteins and their use for extending strawberries postharvest life. Food Hydrocoll., 83, 375-392.

Hasheminejad, N., Khodaiyan, F., 2020. The effect of clove essential oil loaded chitosan nanoparticles on the shelf life and quality of pomegranate arils. Food Chem., 309, 125520.

Holzwarth, M., Korhummel, S., Carle, R., Kammerer, D.R., 2012. Impact of enzymatic mash maceration and storage on anthocyanin and color retention of pasteurized strawberry purées. Eur. Food Res. Technol., 234 (2), 207-222.

Kalaivani, R., Maruthupandy, M., Muneeswaran, T., Singh, M., Sureshkumar, S., Anand, M., Kumaraguru, A.K., 2020. Chitosan mediated gold nanoparticles against pathogenic bacteria, fungal strains and MCF-7 cancer cells. Int. J. Biol. Macromol. 146, 560-568.

Khalifa, I., Barakat, H., El-Mansy, H.A., Soliman, S.A., 2016. Improving the shelf-life stability of apple and strawberry fruits applying chitosan-incorporated olive oil processing residues coating. Food Packag. Shelf Life, 9, 10-19.

Khan, I., Tango, C.N., Chelliah, R., Oh, D.H., 2019. Development of antimicrobial edible coating based on modified chitosan for the improvement of strawberries shelf life. Food Sci. Biotechnol., 28 (4), 1257-1264.

Kumar, S., Ye, F., Dobretsov, S., Dutta, J., 2019. Chitosan nanocomposite coatings for food, paints, and water treatment applications. Appl. Sci., 9 (12), 2409.

Li, J., Fu, Y., Yan, J., Song, H., Jiang, W., 2019. Forced air precooling enhanced storage quality by activating the antioxidant system of mango fruits. J. Food Qual., 2019, 1606058.

Liu, C., Zheng, H., Sheng, K., Liu, W., Zheng, L., 2018a. Effects of melatonin treatment on the postharvest quality of strawberry fruit. Postharvest Biol. Technol., 139, 47-55.

Liu, H., Jiang, W., Cao, J., Ma, L., 2018b. A combination of 1methylcyclopropene treatment and intermittent warming alleviates chilling injury and affects phenolics and antioxidant activity of peach fruit during storage. Sci. Hort., 229, 175-181.

Melo, N.F., de MendonçaSoares, B.L., Diniz, K.M., Leal, C.F., Canto, D., Flores, M.A., Stamford, T.C., 2018. Effects of fungal chitosan nanoparticles as eco-friendly edible coatings on the quality of postharvest table grapes. Postharvest Biol. Technol., 139, 56-66.

Mondal, M.F., 2000. Production and Storage of Fruits (in Bangla). Published by Mrs. Afia Mondal, BAU Campus, Mymensingh-2202, 312.

Moradinezhad, F., Jahani, M., 2019. Effect of potassium permanganate, 1-Methylcyclopropene and modified atmosphere packaging on postharvest losses and quality of fresh apricot cv. Shahroudi. J. Hort. Postharvest Res., 2, 3948.

Nguyen, V.T., Nguyen, D.H., Nguyen, H.V., 2020. Combination effects of calcium chloride and nano-chitosan on the postharvest quality of strawberry (Fragaria $x$ ananassa Duch.). Postharvest Biol. Technol., 162, 111103.

Otoni, C.G., Avena-Bustillos, R.J., Azeredo, H.M., Lorevice, M.V., Moura, M.R., Mattoso, L.H., McHugh, T.H., 2017. Recent advances on edible films based on fruits and vegetables- a review. Compr. Rev. Food Sci. Food Saf., 16 (5), 1151-1169.

Qamar, J., Ejaz, S., Anjum, M.A., Nawaz, A., Hussain, S., Ali, S., Saleem, S., 2018. Effect of aloe Vera gel, chitosan and sodium alginate based edible coatings on postharvest quality of refrigerated strawberry fruits of cv. chandler. Chandler. J. Hortic. Sci. Technol., 1, 8-16.

Qin, Y., Liu, D., Wu, Y., Yuan, M., Li, L., Yang, J., 2015. Effect of PLA/PCL/cinnamaldehyde antimicrobial packaging on physicochemical and microbial quality of button mushroom (Agaricus bisporus). Postharvest Biol. Technol., 99, 73-79.

Rahimi, B.A., Shankarappa, T.H., Krishna, H.C., Mushrif, S.K., Vasudeva, K.R., Sadananda, G.K., Masoumi, A., 2018. Chitosan and $\mathrm{CaCl}_{2}$ coatings on physicochemical and shelf life of strawberry fruits (Fragaria $x$ ananassa Duch.). Int. J. Curr. Microbiol. App. Sci., 7 (7), 3293-3300.

Rani, Z.T., Hugo, A., Hugo, C.J., Vimiso, P., Muchenje, V., 2017. Effect of post-slaughter handling during distribution on microbiological quality and safety of meat in the formal and informal sectors of South Africa: a review. S. Afr. J. Anim. Sci., 47 (3), 255-267.

Roy, A., Bulut, O., Some, S., Mandal, A.K., Yilmaz, M.D., 2019. Green synthesis of silver nanoparticles: biomoleculenanoparticle organizations targeting antimicrobial activity. RSC Adv., 9 (5), 2673-2702.

Svagan, A.J., Hedenqvist, M.S., Berglund, L., 2009. Reduced water vapour sorption in cellulose nanocomposites with starch matrix. Compos. Sci. Technol., 69 (3-4), 500-506.

Tesfaye, B., 2019. An Investigation of Tomato Handling Practices and Its Postharvest Losses Along Supply Chain: The Case of Adea Wereda, East Shoa, Ethiopia. MSc Thesis, College of Development Studies, Addis Ababa University, Ethiopia.

Thakur, R., Pristijono, P., Golding, J.B., Stathopoulos, C.E., Scarlett, C.J., Bowyer, M., Vuong, Q.V., 2018. Development 
and application of rice starch based edible coating to improve the postharvest storage potential and quality of plum fruit (Prunus salicina). Sci. Hort., 237, 59-66.

Vargas, M., Albors, A., Chiralt, A., González-Martínez, C., 2006. Quality of cold-stored strawberries as affected by chitosanoleic acid edible coatings. Postharvest Biol. Technol., 41 (2), 164-171.

Vimal, S., Majeed, S.A., Taju, G., Nambi, K.S., Raj, N.S., Madan, N., Hameed, A.S., 2013. RETRACTED: Chitosan tripolyphosphate (CS/TPP) nanoparticles: Preparation, characterization and application for gene delivery in shrimp. Acta Tropica. 128 (3), 486-93.

Xi, Y., Fan, X., Zhao, H., Li, X., Cao, J., Jiang, W., 2017. Postharvest fruit quality and antioxidants of nectarine fruit as influenced by chlorogenic acid. LWT-Food Sci. Technol., 75, 537-544.

Younes, I., Rinaudo, M., 2015. Chitin and chitosan preparation from marine sources. Structure, properties and applications. Marine Drugs, 13 (3), 1133-1174.

Zhang, L., Chen, F., Lai, S., Wang, H., Yang, H., 2018. Impact of soybean protein isolate-chitosan edible coating on the softening of apricot fruit during storage. LWT Food Sci. Technol., 96, 604-611.

Zorraquín-Peña, I., Cueva, C., Bartolomé, B., Moreno-Arribas, M., 2020. Silver nanoparticles against foodborne bacteria. Effects at intestinal level and health limitations. Microorganisms, 8 (1), 132. 
Table 1. Effect of coating with $\mathrm{CH}$ or $\mathrm{CHNPs}$ on \% weight loss of strawberry fruits during storage at different temperatures.

\begin{tabular}{|c|c|c|c|c|c|c|c|c|c|c|}
\hline \multirow{2}{*}{ Treatment } & & \multicolumn{4}{|c|}{$\begin{array}{c}\text { Storage period (day) } \\
\text { at } 25 \pm 3^{\circ} \mathrm{C}\end{array}$} & \multicolumn{5}{|c|}{$\begin{array}{c}\text { Storage period (day) } \\
\text { at } 6 \pm 2^{\circ} \mathrm{C}\end{array}$} \\
\hline & & $\mathbf{0}$ & 2 & 4 & 6 & $\mathbf{0}$ & 4 & 8 & 12 & 16 \\
\hline Control & & 0.0 & $5.80^{\mathrm{Ca}}$ & $11.50^{\mathrm{Ba}}$ & $28.00^{\mathrm{Aa}}$ & 0.0 & $2.35^{\mathrm{Da}}$ & $4.35^{\mathrm{Ca}}$ & $8.35^{\mathrm{Ba}}$ & $13.65^{\mathrm{Aa}}$ \\
\hline \multirow{2}{*}{$\mathrm{CH}$} & $0.5 \%$ & 0.0 & $4.50^{\mathrm{Cb}}$ & $8.85^{\mathrm{Bb}}$ & $23.00^{\mathrm{Ab}}$ & 0.0 & $2.20^{\mathrm{Da}}$ & $2.95^{\mathrm{Cb}}$ & $4.90^{\mathrm{Bb}}$ & $9.75^{\mathrm{Ab}}$ \\
\hline & $1 \%$ & 0.0 & $4.30^{\mathrm{Cb}}$ & $7.80^{\mathrm{Bc}}$ & $18.20^{\mathrm{Ac}}$ & 0.0 & $2.00^{\mathrm{Da}}$ & $2.60^{\mathrm{Cb}}$ & $3.49^{\mathrm{Bc}}$ & $5.80^{\mathrm{Ac}}$ \\
\hline \multirow{2}{*}{ CHNPs } & $0.5 \%$ & 0.0 & $4.20^{\mathrm{Cb}}$ & $7.41^{\mathrm{Bc}}$ & $16.00^{\mathrm{Ad}}$ & 0.0 & $2.15^{\mathrm{Da}}$ & $2.70^{\mathrm{Cb}}$ & $3.35^{\mathrm{Bc}}$ & $5.50^{\mathrm{Ac}}$ \\
\hline & $1 \%$ & 0.0 & $4.10^{\mathrm{Cb}}$ & $6.50^{\mathrm{Bd}}$ & $13.50^{\mathrm{Ae}}$ & 0.0 & $1.95^{\mathrm{Da}}$ & $2.55^{\mathrm{Cb}}$ & $3.10^{\mathrm{Bc}}$ & $3.85^{\mathrm{Ad}}$ \\
\hline
\end{tabular}

Means values in the same row (as a capital letter) or column (as a small letter) with different letters are significantly different $(p \leq 0.05)$. $\mathrm{CH}$ : chitosan and CHNPS: chitosan nanoparticles.

Table 2. Effect of coating with $\mathrm{CH}$ or CHNPs on total soluble solids (\%) of strawberry during storage at different temperatures.

\begin{tabular}{|c|c|c|c|c|c|c|c|c|c|c|}
\hline \multirow[t]{2}{*}{ Treatment } & & \multicolumn{4}{|c|}{$\begin{array}{l}\text { Storage period (day) } \\
\text { at } 25 \pm 3^{\circ} \mathrm{C}\end{array}$} & \multicolumn{5}{|c|}{$\begin{array}{c}\text { Storage period (day) } \\
\text { at } 6 \pm 2^{\circ} \mathrm{C}\end{array}$} \\
\hline & & 0 & 2 & 4 & 6 & $\mathbf{0}$ & 4 & 8 & 12 & 16 \\
\hline Control & & $5.70^{\mathrm{Ba}}$ & $6.58^{\mathrm{Aa}}$ & $\mathrm{ND}$ & $\mathrm{ND}$ & $5.70^{\mathrm{Aa}}$ & $5.87^{\mathrm{Aa}}$ & $5.65^{\mathrm{Ab}}$ & ND & ND \\
\hline \multirow{2}{*}{$\mathrm{CH}$} & $0.5 \%$ & $5.70^{\mathrm{Ba}}$ & $6.00^{\mathrm{ABb}}$ & $6.12^{\mathrm{Aa}}$ & ND & $5.70^{\mathrm{Aa}}$ & $5.81^{\mathrm{Aa}}$ & $5.75^{\mathrm{Aab}}$ & $5.66^{\mathrm{Ac}}$ & ND \\
\hline & $1 \%$ & $5.60^{\mathrm{Ba}}$ & $5.90^{\mathrm{ABb}}$ & $6.05^{\mathrm{Aa}}$ & ND & $5.60^{\mathrm{Aa}}$ & $5.72^{\mathrm{Aa}}$ & $5.81^{\mathrm{Aab}}$ & $5.74^{\mathrm{Abc}}$ & $5.56^{\mathrm{Ab}}$ \\
\hline \multirow{2}{*}{ CHNPs } & $0.5 \%$ & $5.80^{\mathrm{Ba}}$ & $6.00^{\mathrm{ABb}}$ & $6.22^{\mathrm{Aa}}$ & ND & $5.80^{\mathrm{Ba}}$ & $5.93^{\mathrm{ABa}}$ & $6.03^{\mathrm{ABa}}$ & $6.19^{\mathrm{Aa}}$ & $6.10^{\mathrm{ABa}}$ \\
\hline & $1 \%$ & $5.70^{\mathrm{Ca}}$ & $5.83^{\mathrm{BCb}}$ & $6.18^{\mathrm{ABa}}$ & $6.23^{\mathrm{A}}$ & $5.70^{\mathrm{Ba}}$ & $5.71^{\mathrm{Ba}}$ & $5.79^{\mathrm{ABab}}$ & $5.97^{\mathrm{Aab}}$ & $5.95^{\mathrm{Aa}}$ \\
\hline
\end{tabular}

Means values in the same row (as a capital letter) or column (as a small letter) with different letters are significantly different $(p \leq 0.05)$. CH: chitosan and CHNPS: chitosan nanoparticles, and (ND): not determined.

Table 3. Effect of coating with $\mathrm{CH}$ or CHNPs on total acidity of strawberry during storage at different temperatures.

\begin{tabular}{|c|c|c|c|c|c|c|c|c|c|c|}
\hline \multirow{2}{*}{ Treatment } & & \multicolumn{4}{|c|}{$\begin{array}{c}\text { Storage period (day) } \\
\text { at } 25 \pm 3^{\circ} \mathrm{C}\end{array}$} & \multicolumn{5}{|c|}{$\begin{array}{l}\text { Storage period (day) } \\
\text { at } 6 \pm 2{ }^{\circ} \mathrm{C}\end{array}$} \\
\hline & & $\mathbf{0}$ & 2 & 4 & 6 & $\mathbf{0}$ & 4 & 8 & 12 & 16 \\
\hline Control & & $0.48^{\mathrm{Aa}}$ & $0.37^{\mathrm{Ba}}$ & ND & ND & $0.48^{\mathrm{Aa}}$ & $0.41^{\mathrm{Aa}}$ & $0.38^{\mathrm{Aa}}$ & ND & ND \\
\hline \multirow[b]{2}{*}{$\mathrm{CH}$} & $0.5 \%$ & $0.52^{\mathrm{Aa}}$ & $0.45^{\mathrm{ABa}}$ & $0.34^{\mathrm{Ba}}$ & ND & $0.52^{\mathrm{Aa}}$ & $0.48^{\mathrm{Aa}}$ & $0.46^{\mathrm{Aa}}$ & $0.44^{\mathrm{Aa}}$ & ND \\
\hline & $1 \%$ & $0.51^{\mathrm{Aa}}$ & $0.47^{\mathrm{ABa}}$ & $0.36^{\mathrm{Ba}}$ & ND & $0.51^{\mathrm{Aa}}$ & $0.47^{\mathrm{Aa}}$ & $0.46^{\mathrm{Aa}}$ & $0.44^{\mathrm{Aa}}$ & $0.42^{\mathrm{Aa}}$ \\
\hline \multirow{2}{*}{ CHNPs } & $0.5 \%$ & $0.53^{\mathrm{Aa}}$ & $0.48^{\mathrm{Aa}}$ & $0.43^{\mathrm{Aa}}$ & ND & $0.53^{\mathrm{Aa}}$ & $0.49^{\mathrm{Aa}}$ & $0.47^{\mathrm{Aa}}$ & $0.45^{\mathrm{Aa}}$ & $0.43^{\mathrm{Aa}}$ \\
\hline & $1 \%$ & $0.52^{\mathrm{Aa}}$ & $0.49^{\mathrm{Aa}}$ & $0.43^{\mathrm{Aa}}$ & $0.40^{\mathrm{A}}$ & $0.52^{\mathrm{Aa}}$ & $0.50^{\mathrm{Aa}}$ & $0.48^{\mathrm{Aa}}$ & $0.45^{\mathrm{Aa}}$ & $0.44^{\mathrm{Aa}}$ \\
\hline
\end{tabular}

Means values in the same row (as a capital letter) or column (as a small letter) with different letters are significantly different $(p \leq 0.05)$. CH: chitosan and CHNPS: chitosan nanoparticles, and (ND): not determined. 
Table 4. Effect of coating with $\mathrm{CH}$ or CHNPs on the anthocyanin content $(\mathrm{mg} / 100 \mathrm{~g})$ during storage at different temperatures.

\begin{tabular}{|c|c|c|c|c|c|c|c|c|c|c|}
\hline \multirow{2}{*}{ Treatment } & & \multicolumn{4}{|c|}{$\begin{array}{c}\text { Storage period (day) } \\
\text { at } 25 \pm 3^{\circ} \mathrm{C}\end{array}$} & \multicolumn{5}{|c|}{$\begin{array}{c}\text { Storage period (day) } \\
\text { at } 6 \pm 2^{\circ} \mathrm{C}\end{array}$} \\
\hline & & 0 & 2 & 4 & 6 & $\mathbf{0}$ & 4 & 8 & 12 & 16 \\
\hline Control & & $32.52^{\mathrm{Ba}}$ & $52.76^{\mathrm{Aa}}$ & ND & ND & $32.52^{\mathrm{Ca}}$ & $44.68^{\mathrm{Aa}}$ & $38.36^{\mathrm{Bc}}$ & ND & ND \\
\hline \multirow{2}{*}{$\mathrm{CH}$} & $0.5 \%$ & $32.73^{\mathrm{Ca}}$ & $48.88^{\mathrm{Ab}}$ & $44.60^{\mathrm{Bd}}$ & ND & $32.73^{\mathrm{Ca}}$ & $39.62^{\mathrm{Bb}}$ & $43.80^{\mathrm{Aa}}$ & $33.50^{\mathrm{Cc}}$ & ND \\
\hline & $1 \%$ & $32.13^{\mathrm{Ba}}$ & $47.40^{\mathrm{Abc}}$ & $47.80^{\mathrm{Ac}}$ & ND & $32.13^{\mathrm{Da}}$ & $37.00^{\mathrm{Cc}}$ & $41.25^{\mathrm{Bb}}$ & $48.20^{\mathrm{Aa}}$ & $40.17^{\mathrm{Bb}}$ \\
\hline \multirow{2}{*}{ CHNPs } & $0.5 \%$ & $32.52^{\mathrm{Ca}}$ & $47.00^{\mathrm{Bbc}}$ & $50.96^{\mathrm{Ab}}$ & ND & $32.52^{\mathrm{Da}}$ & $36.92^{\mathrm{Cc}}$ & $41.98^{\mathrm{Bab}}$ & $49.35^{\mathrm{Aa}}$ & $47.25^{\mathrm{Aa}}$ \\
\hline & $1 \%$ & $32.69^{\mathrm{Da}}$ & $46.58^{\mathrm{Cc}}$ & $54.70^{\mathrm{Ba}}$ & $58.25^{\mathrm{Ac}}$ & $32.69^{\mathrm{Ca}}$ & $34.57^{\mathrm{Cd}}$ & $38.00^{\mathrm{Bc}}$ & $45.75^{\mathrm{Ab}}$ & $45.56^{\mathrm{Aa}}$ \\
\hline
\end{tabular}

Means values in the same row (as a capital letter) or column (as a small letter) with different letters are significantly different $(p \leq 0.05)$. CH: chitosan and CHNPS: chitosan nanoparticles, and (ND): not determined.

Table 5. Effect of coating with $\mathrm{CH}$ or CHNPs on the malondialdehyde concentration ( $\mathrm{mmol} / \mathrm{g}$, FW) during storage at different temperatures.

\begin{tabular}{lcccccccccc}
\hline \multirow{2}{*}{ Treatment } & \multicolumn{3}{c}{$\begin{array}{c}\text { Storage period (day) } \\
\text { at } 25 \pm 3^{\circ} \mathbf{C}\end{array}$} & \multicolumn{5}{c}{$\begin{array}{c}\text { Storage period (day) } \\
\text { at } \mathbf{6} \pm 2^{\circ} \mathbf{C}\end{array}$} \\
\cline { 2 - 10 } & & $\mathbf{0}$ & $\mathbf{2}$ & $\mathbf{4}$ & $\mathbf{6}$ & $\mathbf{0}$ & $\mathbf{4}$ & $\mathbf{8}$ & $\mathbf{1 2}$ & $\mathbf{1 6}$ \\
\hline \multirow{2}{*}{ Control } & & $2.45^{\mathrm{Aa}}$ & $3.95^{\mathrm{Aa}}$ & $\mathrm{ND}$ & $\mathrm{ND}$ & $2.45^{\mathrm{Ca}}$ & $3.00^{\mathrm{Ba}}$ & $4.29^{\mathrm{Aa}}$ & $\mathrm{ND}$ & $\mathrm{ND}$ \\
\multirow{2}{*}{$\mathrm{CH}$} & $0.5 \%$ & $2.45^{\mathrm{Ca}}$ & $3.50^{\mathrm{Bb}}$ & $4.65^{\mathrm{Aa}}$ & $\mathrm{ND}$ & $2.45^{\mathrm{Da}}$ & $2.82^{\mathrm{Cab}}$ & $3.45^{\mathrm{Bb}}$ & $4.53^{\mathrm{Aa}}$ & $\mathrm{ND}$ \\
& $1 \%$ & $2.45^{\mathrm{Ca}}$ & $3.38^{\mathrm{Bb}}$ & $4.38^{\mathrm{Aab}}$ & $\mathrm{ND}$ & $2.45^{\mathrm{Ea}}$ & $2.73^{\mathrm{Dbc}}$ & $3.26^{\mathrm{Cbc}}$ & $3.88^{\mathrm{Bb}}$ & $5.53^{\mathrm{Aa}}$ \\
& $0.5 \%$ & $2.45^{\mathrm{Ca}}$ & $3.39^{\mathrm{Bb}}$ & $4.35^{\mathrm{Aab}}$ & $\mathrm{ND}$ & $2.45^{\mathrm{Da}}$ & $2.69^{\mathrm{Dbc}}$ & $3.18^{\mathrm{Ccd}}$ & $3.90^{\mathrm{Bb}}$ & $5.62^{\mathrm{Aa}}$ \\
$\mathrm{CHNPs}$ & $1 \%$ & $2.45^{\mathrm{Da}}$ & $3.28^{\mathrm{Cb}}$ & $4.21^{\mathrm{Bb}}$ & $5.04^{\mathrm{A}}$ & $2.45^{\mathrm{Da}}$ & $2.58^{\mathrm{Dc}}$ & $3.00^{\mathrm{Cd}}$ & $3.75^{\mathrm{Bb}}$ & $5.18^{\mathrm{Ab}}$ \\
\hline
\end{tabular}

Means values in the same row (as a capital letter) or column (as a small letter) with different letters are significantly different $(p \leq 0.05)$. CH: chitosan and CHNPS: chitosan nanoparticles, and (ND): not determined.

Table 6. Effect of coating with $\mathrm{CH}$ or CHNPs on visual decay percentage during storage at different temperatures.

\begin{tabular}{lcccccccc}
\multirow{2}{*}{ Treatment } & & \multicolumn{3}{c}{$\begin{array}{c}\text { Storage period (day) } \\
\mathbf{a t} \mathbf{2 5} \mathbf{3}^{\circ} \mathbf{C}\end{array}$} & \multicolumn{4}{c}{$\begin{array}{c}\text { Storage period (day) } \\
\mathbf{a t} \mathbf{6} \pm \mathbf{2}^{\circ} \mathbf{C}\end{array}$} \\
\cline { 3 - 9 } & & $\mathbf{2}$ & $\mathbf{4}$ & $\mathbf{6}$ & $\mathbf{4}$ & $\mathbf{8}$ & $\mathbf{1 2}$ & $\mathbf{1 6}$ \\
\cline { 3 - 9 } Control & & 10 & 80 & 100 & 15 & 45 & 100 & 100 \\
& $0.5 \%$ & 0 & 40 & 100 & 0 & 10 & 60 & 100 \\
$\mathrm{CH}$ & $1 \%$ & 0 & 30 & 75 & 0 & 0 & 20 & 70 \\
\multirow{2}{*}{$\mathrm{CHNPS}$} & $0.5 \%$ & 0 & 20 & 70 & 0 & 0 & 25 & 60 \\
& $1 \%$ & 0 & 10 & 50 & 0 & 0 & 10 & 40 \\
\hline
\end{tabular}

$\mathrm{CH}$ : chitosan and CHNPS: chitosan nanoparticles. 
Table 7. Effect of coating with $\mathrm{CH}$ or CHNPs on total bacterial count (log CFU/g) of strawberry fruits during storage at different temperatures.

\begin{tabular}{|c|c|c|c|c|c|c|c|c|c|c|}
\hline \multicolumn{11}{|c|}{ Total bacterial count $(\log \mathrm{CFU} / \mathrm{g})$} \\
\hline \multirow{2}{*}{ Treatment } & & \multicolumn{4}{|c|}{$\begin{array}{c}\text { Storage period (day) } \\
\text { at } 25 \pm 3^{\circ} \mathrm{C} \\
\end{array}$} & \multicolumn{5}{|c|}{$\begin{array}{c}\text { Storage period (day) } \\
\text { at } 6 \pm 2^{\circ} \mathrm{C} \\
\end{array}$} \\
\hline & & $\mathbf{0}$ & 2 & 4 & 6 & $\mathbf{0}$ & 4 & 8 & 12 & 16 \\
\hline Control & & 2.65 & 4.37 & 5.97 & ND & 2.65 & 4.96 & 6.65 & ND & ND \\
\hline \multirow[t]{2}{*}{$\mathrm{CH}$} & $0.5 \%$ & 2.63 & 3.95 & 5.63 & ND & 2.63 & 3.31 & 4.58 & 6.23 & ND \\
\hline & $1 \%$ & 2.60 & 3.62 & 5.04 & 6.15 & 2.60 & 3.30 & 4.01 & 5.05 & 6.20 \\
\hline \multirow{2}{*}{ CHNPs } & $0.5 \%$ & 2.62 & 3.69 & 5.00 & 6.10 & 2.62 & 3.25 & 3.88 & 5.18 & 6.23 \\
\hline & $1 \%$ & 2.59 & 3.45 & 4.62 & 5.68 & 2.59 & 3.21 & 3.56 & 4.70 & 5.58 \\
\hline \multicolumn{11}{|c|}{ Mold and yeast count $(\log \mathrm{CFU} / \mathrm{g})$} \\
\hline Control & & 2.28 & 4.02 & 5.85 & ND & 2.28 & 3.89 & 5.82 & ND & ND \\
\hline \multirow[t]{2}{*}{$\mathrm{CH}$} & $0.5 \%$ & 2.25 & 3.90 & 5.60 & ND & 2.25 & 3.65 & 5.10 & 6.15 & ND \\
\hline & $1 \%$ & 2.22 & 3.83 & 5.15 & 5.92 & 2.22 & 3.47 & 4.78 & 5.43 & 6.09 \\
\hline \multirow{2}{*}{ CHNPs } & $0.5 \%$ & 2.23 & 3.85 & 5.05 & 5.83 & 2.23 & 3.55 & 4.73 & 5.30 & 5.91 \\
\hline & $1 \%$ & 2.20 & 3.42 & 4.58 & 5.51 & 2.20 & 3.19 & 4.45 & 5.19 & 5.68 \\
\hline
\end{tabular}

$\mathrm{CH}$ : chitosan and CHNPS: chitosan nanoparticles, and (ND): not determined

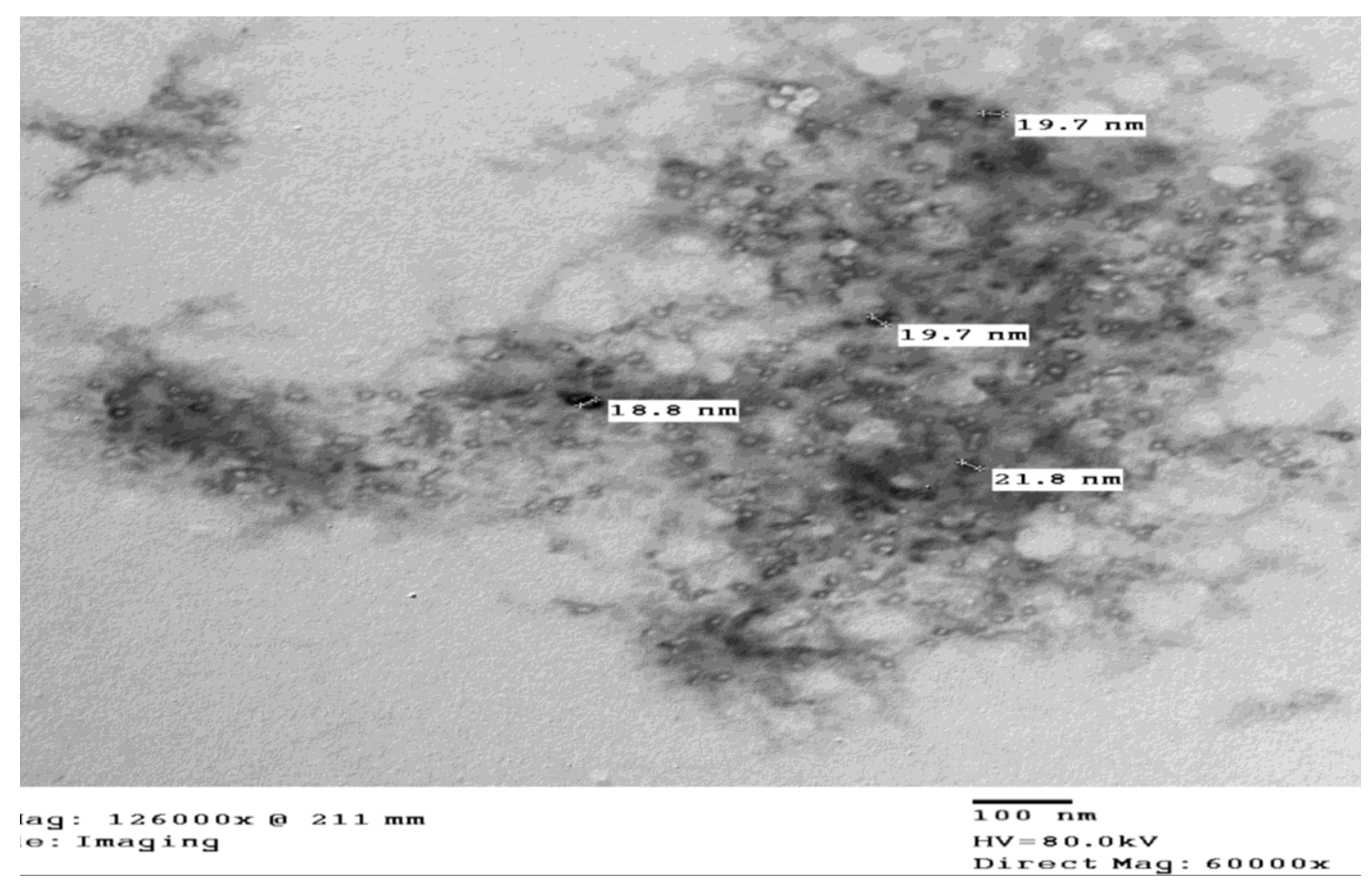

Figure 1. Transmission electron microscopy micrograph of chitosan nanoparticles 


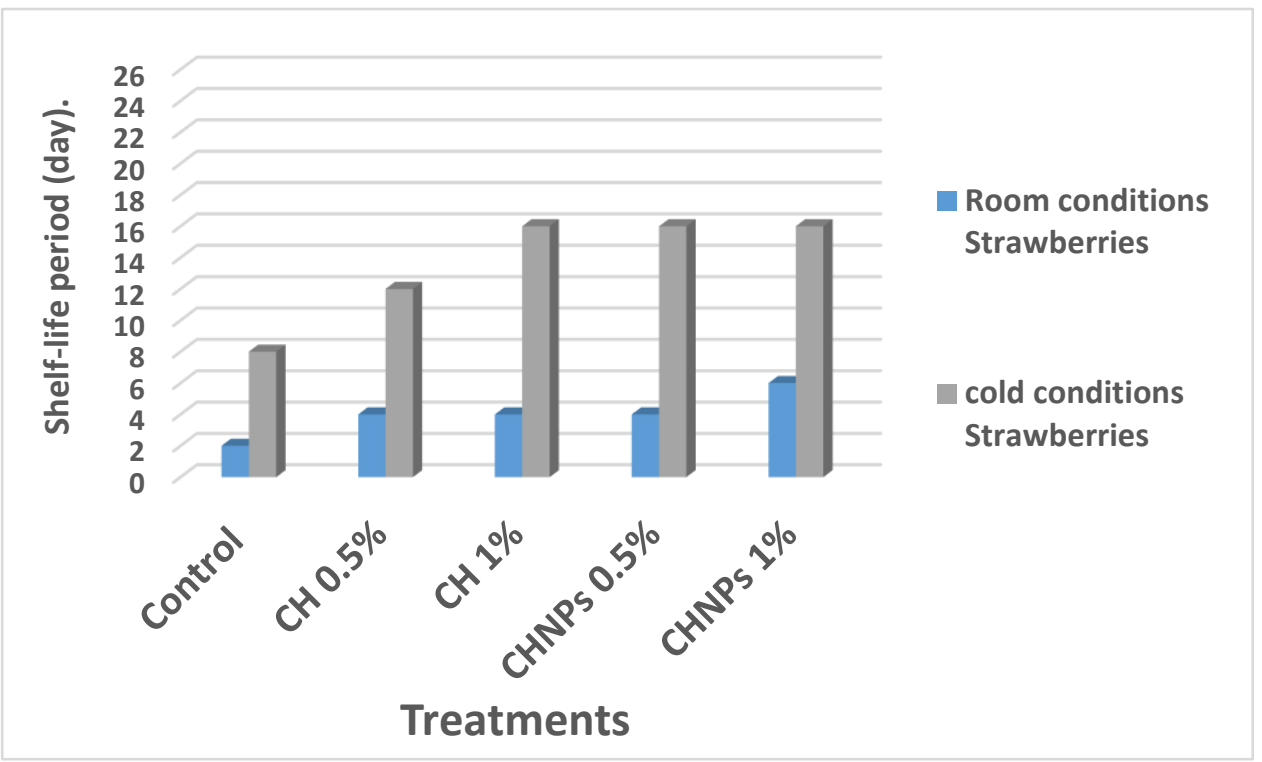

Figure 2. Shelf-life of strawberry fruits. 


\title{
تحسين الجودة والعمر الافتراضى لثار الفراولة المفطاة بالاغشية الصالحة للأكل المتناهية الصغر
}

\author{
محمد شيحات 1، حمد إيراهيم محمد 1، عاطف سعد عشيبة ، إيراهيم محمد طه 1،" \\ 21 قسم علوم وتكنولوجيا الأغذية، كلية الزراعة بالقاهرة، جامعة الأزهر، مدينة نصر، القاهرة، مصر

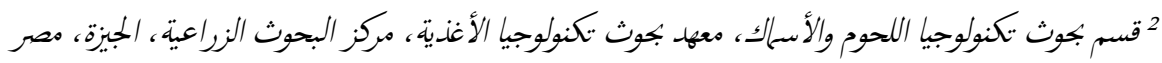

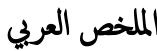

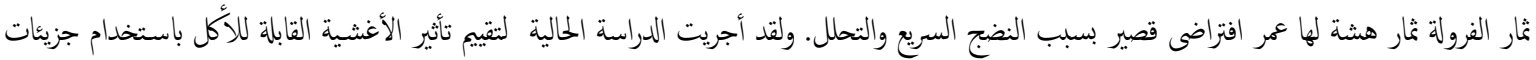

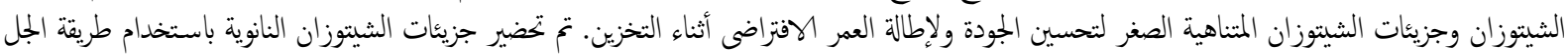

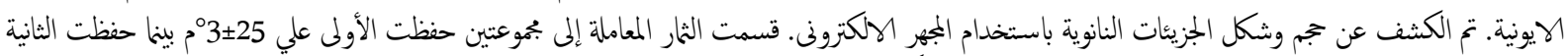

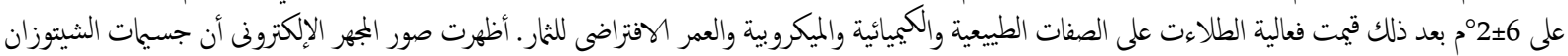

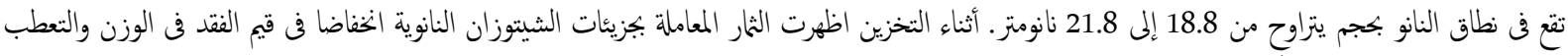

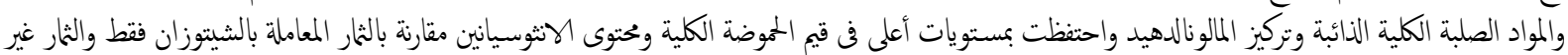

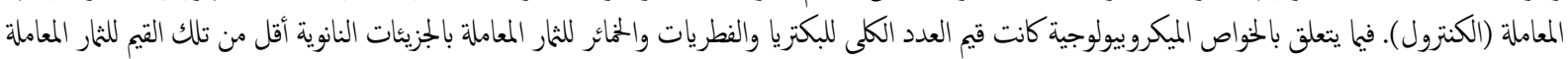

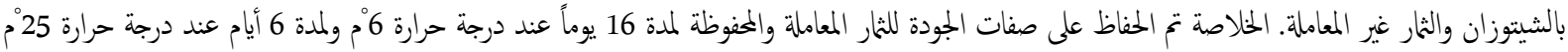

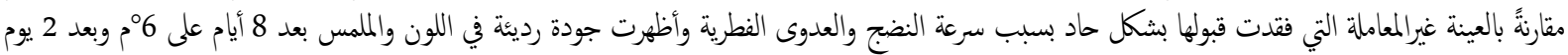

الكلمات الاسترشادية: جزيئات الشيتوزان النانوية، الفراولة، المجهر الإلكتروني، التوصيف، فترة الصلاحية. 